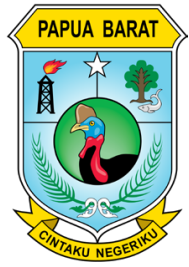

\title{
Manajemen Pengetahuan KebencanaAn yang Lebih Baik Dalam Mendukung Pembangunan Berkelanjutan
}

\author{
Dedi I. Inan* \\ Fakultas Teknik Universitas Papua Manokwari \\ Jl. Gn. Salju, Manokwari, Papua Barat 98314.
}

Dikirim: 15 Oktober 2019; Direvisi: 28 November 2019; Disetujui: 18 Desember 2019

\begin{abstract}
Disaster cannot be prevented. What can be followed up to, therefore, is to response to optimally in a disaster management. The aim is to reduce the impact caused, the losses of properties and the casualties. On the other hand, the concept of sustainable development is an inseparable side of the disaster management activities. This is not surprising as the overarching goals of the Sustainable Development Goals (SDGs) 2030 initiatives are the core of the disaster risk reductions through targets through Sendai Framework of Disaster Risk Reduction 2015-2030. In attempts to externalise it, one of the efficient and considered as the most effective ways is learning from the best practices of the past experiences. Information and Communication Technology through an information system: knowledge-based information system of disaster management, is worth seeking. This is because the various benefits offered by it to expedite and embody it, in particular, the advantage in a geographically and distaces issues. This writing discusses the cutting-the-edge review of the aforementioned ideas. This is conducted through a content analysis of the diverse related works and literatures as the target of the writing. In the end, the flagships of future research directions will be laid out.
\end{abstract}

Keywords: disaster management knowledge, information systems, policy management, decision support systems, sustainable development

\section{Intisari}

Bencana tidak dapat dicegah. Karena itu hal yang dapat dilakukandalam merespon keadaanitu adalah menanganinya dengan seoptimal mungkin. Tujuannya adalah mengurangi dampak yang terjadi, yaitu dampak kerusakan dan kematian. Disisi lain, konsep pembangunan berkelanjutan (sustainable development) merupakan bagian yang tidak terpisahkan dari aktivitas penanggulangan bencana. Hal ini tidak mengherankan karena keseluruhan tujuan inisiatif Susitainable Development Goals (SDGs) 2030 merupakan bagian inti dari berbagai target - target pengurangan resiko bencana Sendai Framework Disater Risk Reduction 2015-2030. Dalam usaha - usaha mewujudkannya, salah satu hal saat ini dianggap paling efisien dan bisa sangat efektif adalah belajar dari pengalaman best practiceaktivitas Pengananan Bencana (PB) sebelumnya. Pemanfaatan Teknologi Informasi dan Komunikasi, melalui sebuah sistem informasi, knowledge-based information system of disaster management, menjadi hal yang perlu diupayakan. Hal ini mengingat berbagai keuntungan yang ditawarkan untuk mempercepatdan mewujudkan hal - hal tersebut, terutama keuntungan yang disebabkan karena tantangan geografis dan jarak. Tulisan ini membahas tentang telaah terkini (cutting the edge) hal - hal yang dijelaskan ini. Telaah dilakukan melalui analisis isi (content analysis) dari berbagai literatur yang menjadi target penelitian. Pada akhirnya, saran dan arah penelitian kedepan akan disampaikan pada bagian akhir tulisan ini.

KataKunci: pengetahuan penanganan bencana, sistem informasi, manajemen kebencanaan, sistem pendukung keputusan,pembangunan berkelanjutan

\footnotetext{
* Korespondensi Penulis 


\section{LATAR BELAKANG}

Secara global, bencana (disaster) memperlihatkan tren yang meningkat secara eksponensial. Kerugian akibat kedua tipe bencana, alam dan teknologi, tersebutpun meningkat secara eksponensial. Hal ini ditunjukan pada Gambar 1. Berbagai keadaan inilah yang kemudian mendorong berbagai usaha yang secara kontinu dilakukan untuk mengurangi dampak yang ditimbulkan karena berbagai hal tersebut (Rivera et al., 2015). Hal ini disebabkan karena telah disadari bahwa bencana tak bisa dicegah. Dengan kata lain, bencana pasti terjadi (Coppola, 2006). Gambar 2 menujukan tren bencana di Indonesia dalam kurun waktu 2003-2017 yang terus meningkat.

Karena itu, hal yang paling mungkin untukdilakukan baik oleh individu maupun organisasi adalah menanggulanginya (manage). Tujuannya adalah agar: (1) bencana tersebut tidak membawa dampak kematian yang terlalu banyak (massive) dan/atau tidak menyebabkan dampak kerusakan: lingkungan, harta benda, dll, yang terlalu besar (UNISDR, 2014); (2) proses respon dan/atau adaptasi terhadap bencana dapat terjadi dalam waktu yang relatif cepat; dan (3) proses pemulihan (recovery)akibat bencana tersebut menjadi lebih cepat dan tepat. Ketiga hal inilah yang kemudian lebih dikenal sebagai usaha-usaha penanggulangan bencana yang tangguh (Disaster Managementresilient endeavour)
(Blackman et al., 2017). Lebih jauh, keseluruhan aktivitasyang bertujuan meminimalisir dampak yang ditimbulkan oleh bencana inilah yang kemudian dikenal sebagai Penanggulangan Bencana(PB) (Disaster Management) (Coppola, 2006).

Perlu ditekankan sedari awal dalam tulisan ini bahwa sejatinya alam tidak menyebabkan bencana (disaster). Alam menghasilkan bahaya (hazard). Namun bahaya tersebut hanya akan berubah menjadi bencana karena ulah manusia (bnpb.go.id, 2019). Curah hujan yang terjadi di tengah Samudera Hindia, misalnya, hanya akan menjadi peristiwa alam yang berbahaya. Hal ini akan berubah menjadi bencana jika terjadi pada daerah padat penduduk dengan sistem pembangunan kawasan yang tidak memperhatikan lingkungan.Bencana banjir bandang (flash flood) yang menewaskan lebih dari 100 jiwa dan mengungsikan lebih dari 11000 lainnya (bnpb.go.id, 2019b; detikcom, 2019) di Sentani Provinsi Papua yang terjadi hanya beberapa waktu lalu sekali lagi menunjukan hal tersebut.

Juga, perlu diingat bahwa secara singkat bencana itu sendiri didefinisikan sebagai kombinasi dari kerusakan yang terjadi pada materi, ekonomi dan lingkungan, termasuk manusia yang ditimbulkan karena kurangnya kapasitas dalam menangkal potensi negatif sebagai konsekuensi karena kerusakan tersebut. Sementara yang dimaksud dengan

\section{Introduction}

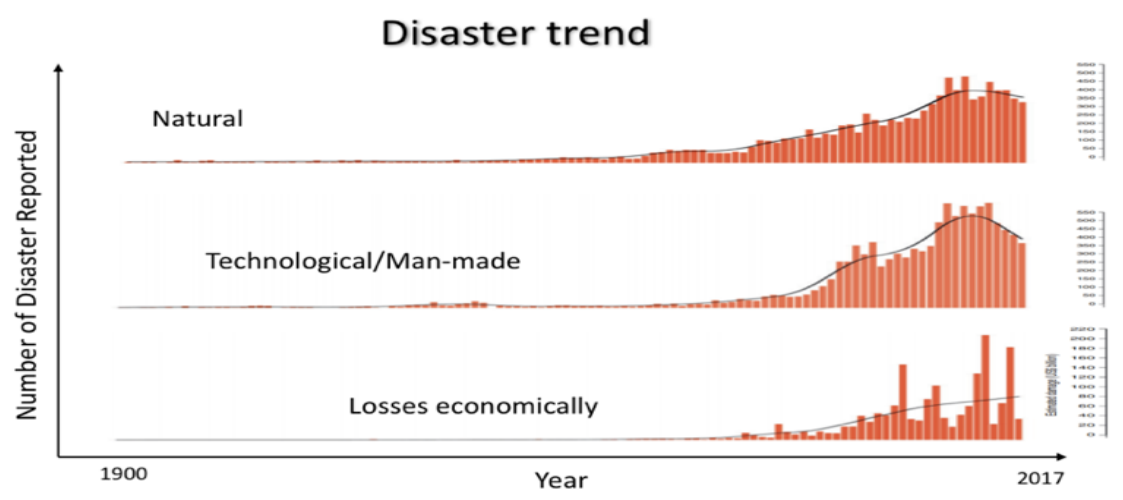

Sumber: www.emdat.be

Gambar 1. Tren Jumlah Bencana yang Dilaporkan dalam Kurun Waktu 1900-2018 (sumber: www.emdat.de). 
TRIEND BENCANA INDONESIA TAHUN2003-2017

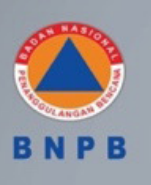

Data di BNPB tercatat ada 2.372 kejadian bencana di Indonesia selama 2017 (per 31-12-2017). Banjir, longsor dan puting beliung masih tetap mendominasi.

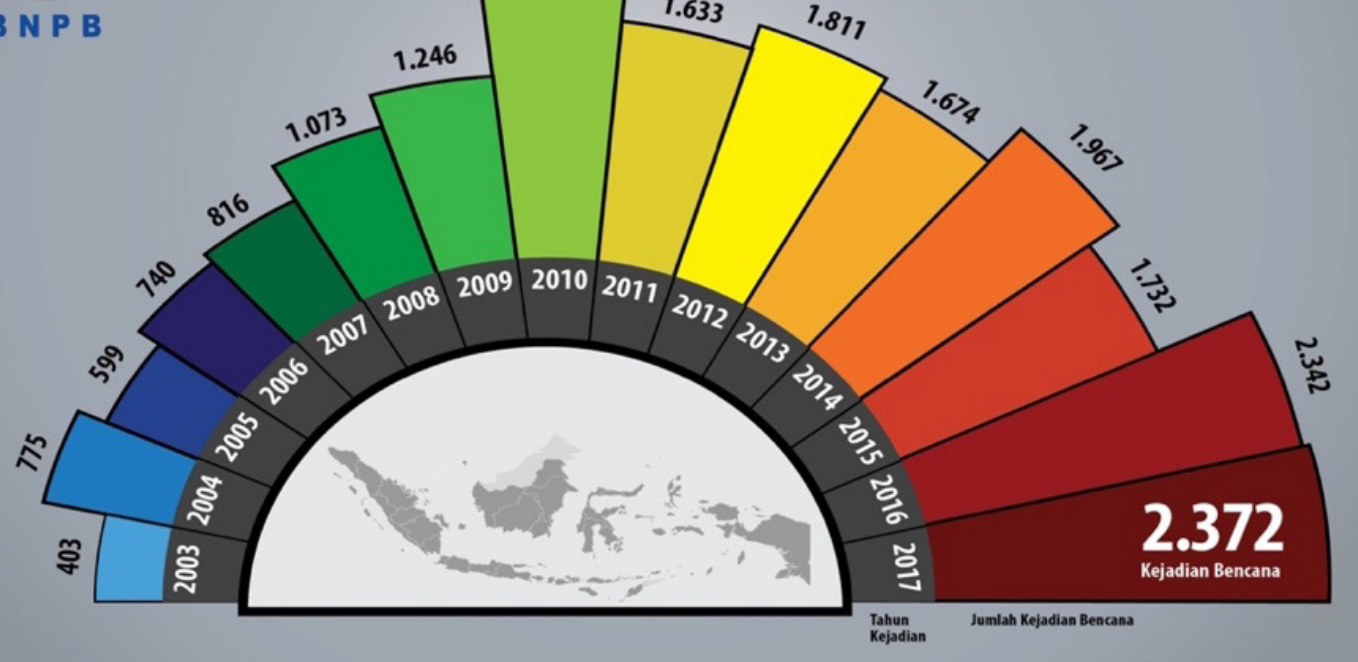

Gambar 2. Tren Peningkatan Penanggulangan Bencana di Indonesia dalam Kurun Waktu 2003-3017 Sumber: BNPP 2018

bahaya adalah sebuah fenomena alam atau aktivitas atau kondisi manusia yang berpotensi menyebabkan kerusakan sebagaimana yang dimaksud sebelumnya.Berbagai usaha telah dilakukan dan diusulkan dalam upaya untuk PB (Chatfield et al., 2014). Kesadaran untuk menkonseptualisasi sebuah proses yang dapat menjamin bahwa adanya proses pembelajaran dari pengetahuan sebelumnyamenjadi hal yang saat ini tidak hanya sangat menantang tapi juga dianggap relatif paling efektif dalam mendukung upaya membangun $\mathrm{PB}$ yang tangguh (UNISDR, 2015).

Disisi lain sejatinya PB yang tangguh adalah bagian dari upaya mewujudkan pembangunan yang berkelanjutan (sustainable development) (UNISDR, 2015). Hal ini tidak mengherankan karena sesungguhnya keseluruhan 17 tujuan dalam Sustainable Development Goals (SDGs) 2030 menjadi bagian dari 25 target pengurangan resiko bencana (disaster risk reduction), sebagaimana yang tertuang dalam Sendai Framework for Disaster Risk Reduction 2015-2030 (UNISDR, 2015).

Oleh karena itu maka berbagai diskusi tentang konsep pembangunan berkelanjutan dan pengurangan resiko bencana sudah seharusnya dilakukan tidak terpisah dan dalam konteks mempercepat dan muwujudkan konsep - konsep tersebut secara efektif. Keterkaitan tujuan dan target dari kedua konsep tersebut memungkinkan berbagai usaha untuk mewujudkannya dapat dilakukan secara pararel dengan sumber daya yang mestinya dapat pakai bersama (resources sharing).

Dalam konteks inilah maka pemanfaatan teknologi, dalam hal ini Teknologi Informasi dan Komunikasi (TIK) sangat mendesak untuk dirangkul. Hal ini karena TIK hadir dengan roh untuk membuat setiap proses dan aktivitas yang TIK terlibat didalamnya menjadi efektif, dapat diselesaikan dengan baik, dan efisien, dilakukan dengan biaya yang relatif lebih murah. Sebagai contoh, bagaimana TIK, dalam hal ini sistem informasi, yang dikembangkan mendorong proses akuntabilitas dan transparansi kerja pemerintah daerah melalui aplikasi e-planning dan e-budgeting, yang saat ini di Provinsi Papua Barat sedang digalakkan penggunaannya, dan lain sebagainya.

Tulisan ini dimaksudkan untuk 
memberikan telaah terbaru (cutting the egde) tentang penelitian yang ada terkait dengan hal-hal yang telah disampaikan diatas. Secara spesifik, tulisan ini berfokus pada sisi PB. Hal ini disebabkankarena secara alamiah, karakteristik dari bencana itu sendiri adalah kompleks dan tak bisa dipastikan(nondeterministic) (Hiwasaki et al., 2015). Dengan kata lain karakteristik sebuah bencana adalah tak bisa ditentukan kapan bencana itu terjadi dan seberapa besar magnitud-nya (besarnya) (Cavallo \& Ireland, 2015). Lebih jauh, dalam sebuah proses $\mathrm{PB}$, berbagai stakeholder (individu/organisasi/institusi) yang terlibat memiliki tujuan, kepentingan dan struktur hirarki yang berbeda (Dorasamy et al., 2017).

Mengingat karakteristik berbagai PB tersebut maka pengetahuan best practices (praktik-praktik terbaik) yang holistik dan tersedia tentang PB (Disaster Management Knowledge) yang dapat diakses dengan mudah oleh berbagai pemangku kepentingan (stakeholders) PB menjadi hal yang relatif fisibel dalam mendukung pengurangan risiko bencana (Inan et al., 2015). Pengetahuan best practices yang lengkap dan holistik ini tidak hanya tersedia pada level pengambilan keputusan (decision making) tapi juga pada level perencanaan/kebijakan (planning/ policy) dan aktivitas di lapangan (real world activities). Karenanya, berbagai pengetahuan tersebut haruslah dapat diolah dan disimpan, yang kemudian dapat dimanfaatkan oleh stakeholders PB lainya untuk keperluan penanganan manajemen bencana yang sejenis yang lebih baik di masa-masa yang akan datang.

Sebagai contoh, dalam sebuah bencana banjir (flood disaster), ketika berbagai indikator mengindikasikan sudah saatnya dilakukan evakuasi maka peringatan evakuasi (evacuation warning) segera dikeluarkan oleh otoritas terkait. Di Indonesia, hal ini dilakukan oleh BPBD (Badan Penanggulangan Bencana Daerah) setempat: Provinsi/Kota/Kabupaten). Badan yang sejenis pada level nasional, yaitu BNPB (Badan Nasional Penanggulangan Bencana) hanya akan mem-backup jika berbagai sumber daya setempat tidak bekerja dengan baik atau kewalahan dalam menghadapi bencana tersebut.

Persoalan-persoalan selanjutnya setelah keputusan itu dibuat adalah bagaimana proses evakuasi tersebut diterjemahkan menjadi pengetahuan yang dapat digunakan sebagai landasan dalam melakukan kegiatan. Oleh karena itu, perlu adanya pengetahuan tentang perencanaan aktivitas PB yang akan dimanfaatkan oleh mereka yang melakukan aktivitas PB pada garis depan proses evakuasi. Misalnya, pengetahuan tentang siapa yang akan melakukan evakuasi, sumber daya apa yang digunakan, kapan harus dilakukan, predan post-condition yang perlu diketahui, dll. Pengetahuan ini haruslah tidak menimbulkan multitafsir atau ambiguitas yang membuat pengetahuan tersebut perlu diinterpretasi lagi saat akan dimanfaatkan. Hal ini disebabkan karena waktu menjadi hal yang sangat krusial yang dapat menimbulkan fatalitis.

Dalam konteks ini, sebuah sistem informasi yang handal, sistem informasi manajemen kebencanaan berbasis pengetahuan (knowledge-based information system of disaster management), menjadi sebuah solusi yang layak diupayakan. Hal ini didorong oleh teknologi pengembangan sistem informasi yang ada saat telah mencapai taraf yang sangat matang. Sistem informasinya ini dimaksudkan untuk membantu berbagai pemangku kepentingan melakukan penanggulangan bencana yanglebih baik. Dan untuk menunjang efektifitas sistem informasi yang dikembangkan tersebut, faktorfaktor kemudahan penggunaan (perceive ease of use) dan kemanfaatan (perceive usefulness) menjadi hal-hal yang dapat relatif dengan mudah diukur.

Tulisan ini diorganisasi sebagai sebagai berikut: Bagian berikutnya melaporkan tentang metodologi yang digunakan. Bagian ketiga menjelaskan tentang hasil yang diperoleh; Bagian keempat menjelaskan tenatng diskusi dan kesimpulan. Selanjutnya bagian kelima adalah tentang agenda riset kedepan yang merupakan hasil dari telaah yang dilakukan pada bagian sebelumnya dan bagian yang terakhir adalah berbagai referensi yang digunakan dalam penelitian ini.

\section{Metode}

Metodologi riset terkait penelitian ini dipresentasikan pada bagian ini, Metodologi tersebut terbagi menjadi beberapa bagian, sebagai berikut: 


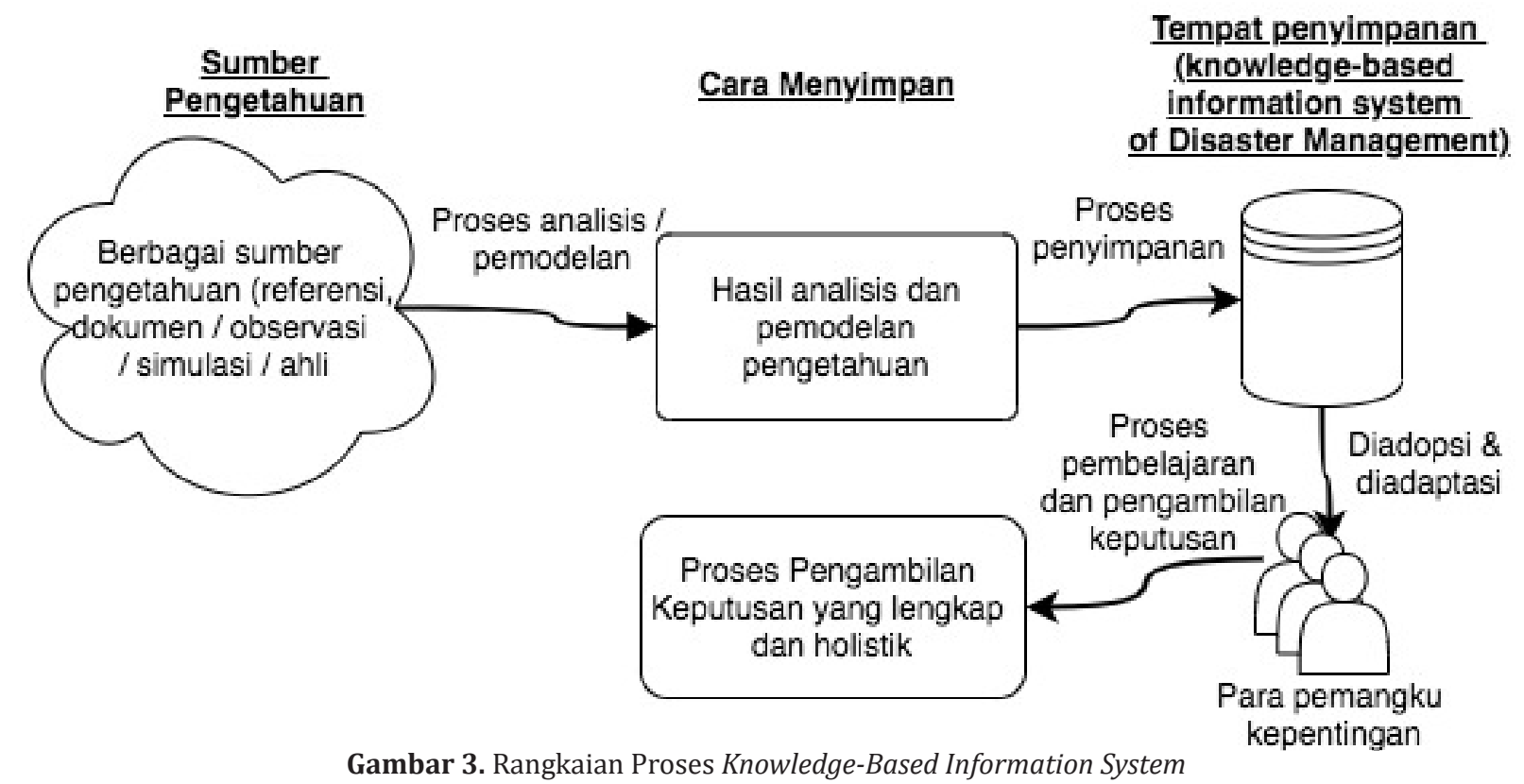

Gambar 3. Rangkaian Proses Knowledge-Based Information System of Disaster Management

\section{a) Isu sentral}

Sebagaimana yang telah dijelaskan pada bagian Pendahuluan pada makalah ini, isu sentral yang dikemukakan adalah terkait pemanfaatan pengetahuanbest practiceproses PB yang ada. Pengetahuan ini kemudian dimungkinkan untuk dapat digunakan kembali (reuse)oleh berbagai stakeholder lainya dalam proses PB sejenis. Dengan demikian maka isu sentralnya yang menjadi konsern pada makalah ini adalah: 1) memotret literatur yang terbaru tentang berbagai metodologi saat ini yang dapat merepresentasikan pengetahuan PB yang menyeluruh dan holistik. Lebih lanjut berbagai metodologi tersebut harus mampu merepresentasikan berbagai kompleksitas pengetahuan proses PB sehingga dapat diikuti dan dipahami oleh berbagai stakeholderlainya yang mengadopsinya; dan 2) meninjau tentang beragam repositori yang sesuai yang terdapat pada literatur terbaru yang dapat digunakan untuk menyimpan pengetahuan yang telah direpresentasikan sebelumnya dari bagian pertama.

Dalam konteks makalah ini, kedua isu ini menjadi sebuah bagian tak terpisahkan dalam usaha mengembangkan ketahanan terhadap bencana. Ini disebabkan karena kedua hal tersebut akan menjadi fondasi bagi proses pengambilan keputusan (decision making process) yang lebih lengkap dan menyeluruh dalam proses PB sejenis lainya.
Pengetahuan best practice yang lengkap ini tidak hanya akan menjadi lesson learn terbaik bagi stakeholder lainya tapi juga akan memberikan landasanproses PB sejenis. Pengetahuan best practice PB tersebut diadopsi dan selanjutnyadiadaptasi sesuai dengan kearifan lokal daerah yang mengadopsinya untuk optimalisasinya berbagai sumber daya yang tersedia. Konsep ini dideskripsikan pada Gambar 3.

Namun demikian, walaupun sangat krusial untuk dilakukan, mewujudkan ide ini adalah hal yang tidak hanya menantang namun juga rumit untuk dilakukanoleh karena: 1) pengetahuan best practice PB tidak mudah untuk dikumpulkan. Pengetahuan tersebut tidak selalu tertulis secara ekplisitdalam dokumen yang mudah diperoleh. Banyak dari pengetahuan tersebut yang masih tersimpan dalam memori para ahli kebencanaan, tercecer pada berbagai dokumen, diberbagai tempat dan bentuk serta sumber (lihat Gambar 2); 2) Jikapun tertulis dalam dokumen yang dapat dengan mudah diperoleh, hal ini tidak berarti bahwa pengetahuan tersebut dapat dengan dipahami mudah. Kebanyakan pengetahuan dalam dokumen tersebut ditulis dalam spesifikasi format bisnis yang malah mempertajam pemisahan yang semakin ketat terkait proses PB yang holistik, yaitu semakin memisahkan fase mitigasi, kesiapsiagaan, respon dan pemulihan; 3) Disisi lain, 
mengkonstruksi pengetahuan PB yang rumit dan kompleks tersebut ternyata sangat sulit oleh karena karakteristik unik dari bencana yang dinamis tersebut; dan 4) repositori yang representatif yang dapat menampung berbagai pengetahuan dengan karakteristik unik tersebut perlu disiapkan. Misalnya, diberbagai negara maju, eq. Australia, best practice pengetahuan PB tersebut dikumpulkan dan diformalisasi oleh otoritas penanganan terkait, yaitu SES (State Emergency Service) Australia. Namun demikian, pengetahuan tersebut ditulis dalam format spesifikasi bisnis yang sulit dimanfaatkan secara langsung oleh mereka yang berada pada garis depan PB. Dilain pihak, di negara sedang berkembang, misalnya Indonesia, pengetahuan tersebut walaupun ada dan telah dimanfaatkan untuk berbagai PB namun tidak dituangkan dalam secara eksplisit sebuah dokumen yang formal yang dapat dimanfaatkan ataupun ditransfer pada stakeholders terkait, misalnya sesama BPBD, untuk diadopsi dan diadaptasi dalam PB sejenis ditempat lain.

\section{b) Seleksi literatur}

Telaah literatur (literature review) pada makalah ini merujuk pada sebuah kerangka yang dijelaskan oleh Webster dan Watson (2002). Fokus tinjauan literatur pada makalah ini sebagaimana yang telah dijelaskan diatas, dibatasi pada literatur akademik yang terbit antara tahun 2007-2019. Proses pencariannya literatur untuk keperluan makalah ini dilakukan pada repositori akademik daring (online) utama , yaitu scopus. Hal ini mengingat scopus adalah repositori akademik daring terbesar (Paré et al., 2015). Proses pencariannya menggunakan kombinasi kata kunci yang terkait, misalnya: "disaster management"atau "emergency management" dan "knowledge management", "disaster management", "sustainable development" dan "knowledge repository". Setelah menyaring duplikasi yang muncul, terdapat 51 literatur yang dimanfaatkan untuk ditinjau. Setelah setiap literatur tersebut diuji secara hati-hati, terdapat hanya 23 literatur yang menjadi rujukan pada makalah ini.

\section{c) Metode analisis}

Analisis isi (content analysis) metodologi digunakan padamakalah ini. Sebagaimana yang telah dijelaskan sebelumnya, analisis isi terhadap makalah yang diperoleh pada tahapan sebelumnya terkait dengan: 1) apakah makalah tersebut berkorelasi dengan pengetahuan $\mathrm{PB}$ dan apakah pengetahuan PB perlu distruktur secara holistik; 2) pemanfaatan sebuah repositori yang dapat dimanfaatkan untuk menyimpan pengetahuan dengan karakteristik yang kompleks dan holistik tersebut; dan 3) berbagai metode tentang bagaimana proses menyimpanan pengetahuan tersebut dilakukan.

\section{Hasil dAN PEMbahasan}

Untuk memudahkan proses mengkonseptualisasi berbagai ide dan gagasan dalam makalah yang telah disaring dari tahapan sebelumnya, maka kategorisasi terhadap isu tersebut diperlukan. Idenya sesuai dengan isu yang telah dipotret dalam penjelasan sebelumnya, sebagai berikut:

\section{A. Pentingnya Mengurai Kekusutan (Intertwined) Pengetahuan PB}

Menginvestigasi pengetahuan best practice telah menjadi konsern yang berkelanjutan dalam riset PB (Briceño, 2015; Fogli et al., 2017; Weichselgartner \& Pigeon, 2015). Hal ini telah disadari sepenuhnya karena tidak ada bencana yang identik yang memungkinkan sebuah formulasi jenerik bisa diterapkan dalam semua kasus (D. Coppola, 2011). Oleh karena itu maka efektifitas dan efisiensi aktivitas PB adalah tentang bagaimana menyediakan pengetahuan best practice $\mathrm{PB}$ yang selengkap mungkin untuk setiap bencana (Blackman et al., 2017; Thapa et al., 2017).

Namun dengan demikian ketersediaan pengetahuan best practice berbagai aktivitas PByang sejenis secara lengkap dan relevan, misalnya: berbagai pengetahuan aktivitas proses PB banjir, erupsi gunung merapi, dll., adalah tidak hanya krusial namun juga pengetahuan tersebut haruslah bisa didekomposisi untuk kepentingan proses pengambilan keputusan yang holistic (Mejri \& Pesaro, 2015; Rivera et al., 2015). Hal ini disebabkan karena berbagai diskrepansi istilah dan pengetahuan digunakan oleh berbagai stake holder dalam proses PB mereka.

Kontribusi dalam ini terdapat dalam beberapa literatur berikut (Delir Haghighi et al., 2013; Mescherin etal., 2013; Wang \& Wu, 2012). 
Idenya adalah mereka memanfaatkan sebuah teknik dalam SI yang dikenal sebagai ontologi, yaitu sebuah teknik untuk "menghubungkan konsepyangsemantiknya sejenis". Hal ini karena faktanya berbagai entitas yang terlibat dalam PB berasal dari latar belakang dan kepentingan yang berbeda. Entitas tersebut memiliki pengetahuan yang berbeda menyangkut banyak hal namun yang sejatinya merujuk pada hal yang sama. Misalnya dalam hal istilah "peningkatan kesadaran publik akan banjir" dan "memberikan pemahaman masyarakat terkait bencana banjir". Kedua istilah tersebut pada prinsipnya secara semantik merujuk pada aktivitas yang sama yaitu "pendidikan publik" (public education). SI sebagai sebuah disiplin menawarkan sebuah metode, yaitu ontologi, untuk menyelesaikan isu ini. Namun demikian, pada literatur tersebut ontologi dimanfaatkan hanya sebatas pada proses merepresentasikan pengetahuan dari berbagai sumber yang telah ada dengan tidak menyelesaikan proses "mengurai kekusutannya" (disentangling) dalam format yang mudah dipahami dalam proses PB secara holistik.

Pada sisi lainya, begitu banyak sumber pengetahuan PB menjadi konsern pada berbagai makalah lainya, misalnya pada makalahmakalah ini (Grolinger et al., 2015; Horita et al., 2017; Poslad et al., 2015). Hal ini disebabkan karena berbagai sumber pengetahuan PB sangat sulit untuk diunifikasi melalui ontologi. Mereka, misalnya mengusulkan pemanfaatan komputasi awan (cloud computing) dalam menyelesaikan isu tersebut. Secara spesifik, masing-masing Poslad et al. (2015) and Horita et al. (2017) mengusulkan pemanfaatan teknologi Internet of Thing (IoT) dan big datasebagai fondasi untuk menyelesaikan isu diskrepansi tersebut. Walaupun secara spesifik tidak dijelaskan prosesnya, namun berbagai manfaat dan karakteristik komputasi awan, IoT dan big data dipandang potensial dalam menyelesaikan diskrepansi pengetahuan best practice $\mathrm{PB}$ tersebut.

Namun demikian, proses pembuatan keputusan (decision support system) yang lebih teringetrasi dan holistik dalam aktivitas PB, belum mampu dijelaskan secara jelas prosesnya. Sementara pada literatur lainya, misalnya Dorasamy et al. (2017), walaupun sebuah manajemen pengetahuan terintegrasi dalam sebuah sistem pendukung keputusan telah dikembangkan namun isu tentang proses mengurai pengetahuan PB dalam struktur yang holistik tetap adadan tidak/belum menjadi jelas.

Sementara itu, pada literatur lainya, misalnya (Inan \& Beydoun, 2017; Inan et al., 2018), isu tentang proses mengurai kekusutan pengetahuan telah diselesaikan dengan mengadopsi metodologi dalam rekayasa pengetahuan (knowledge engineering). Hal ini merupakan bagian dari inti kontribusi penelitian mereka. Namun demikian isu tentang proses pembuatan keputusan kurang mendapat tempat dalam penelitian mereka. Hal ini dapat dipahami karena kontribusi dalam riset mereka adalah tentang proses pengurai kekusutan pengetahuan best practice yang telah menjadi isu sentral dalam domain PB selama beberapa waktu lamanya.

\section{B. Kebutuhan Repositori Pengeta- huan PB yang Representatif}

Kebutuhan tentang sebuah repositori yang tepat, yang mendukung pengetahuan yang telah direpresentasikan dan diurai telah menjadi isu penelitian sejak beberapa waktu lamanya(Blackman et al., 2017). Hal ini karena kesadaran bahwa proses penggunaan kembali pengetahuan tentang aktivitas PB pada PB sejenis lainya memerlukan sebuah repositori yang mendukung. Repositori dimanfaatkan untuk menyimpan pengetahuan best practice yang kemudian akan dimanfaatkan sebagai lesson learnt.

Sebagaimana yang telah dijelaskan sebelumnya bahwa proses pengurai pengetahuan telah menjadi bagian dari kontribusi pada literatur ini (Inan et al., 2018). Dalam kontribusinya, repositori yang diadopsi untuk menyimpan pengetahuan best practice $\mathrm{PB}$ memanfaatkan sebuah model PB yang berada pada level abstraksi model itu sendiri, yang dikenal sebagai istilah metamodel (Beydoun et al., 2009). Hal ini karena dianggap bahwa bentuk metamodeladalah bentuk yang paling tepat sebagai repositori PB karena sifatnya yang menjamin kelengkapan pengetahuan (completeness) (Othmanetal.,2014).Metamodel menghimpun berbagai pengetahuan yang terkait dan menghubungkannya dalam sebuah relasi yang mudah mudah ditelusuri. Dalam hal ini, oleh karena model tersebut dibangun untuk keperluan PB maka kelengkapannya dalam hal 
ini adalah kelengkapan pengetahuan PB.

Pemanfaatan bentuk metamodel sebagai sebuah repositori dalam proses PB telah banyak dibanyak diadopsi, misalnya dalam berbagai literatur berikut ini (Benaben et al., 2016; Chen et al., 2015; Lauras et al., 2015; Othman et al., 2014). Namun demikian, sebagaimana yang ditunjukan oleh Inan et al.(2016) bahwa metamodel yang dikembangkan oleh Othman et al. (2014) adalah yang dianggap paling representatif dalam konteks ini dibanding lainya. Hal ini karena metamodel ini dibangun dengan mempopulasi dan mensintesis 89 model PB yang ada (Othman \& Beydoun, 2016). Oleh karena itu maka dianggap bahwa model tersebut adalah yang terlengkap dan karenanya paling representatif untuk dijadikan sebuah repositori dalam konteks ini.

Namun demikian, metamodel tersebut walaupun telah diekseminasi secara rigor dalam domain akademis namun dalam hal praktis hal tersebut masih harus diuji kembali. Hal ini karena dalam aktivitasnya, dampak PB adalah kerusakan yang nyata dan bahkan dapat menyebabkan kehilangan nyawa. Karenanya menjamin bahwa repositori yang tepat dan bermanfaat adalah hal yang sangat krusial. Dengan demikian, diperlukan berbagai pengujian lanjutan sebagai bentuk kontribusi praktis (practical contribution) dari metamodel yang akan dimanfaatkan sebagai repositori.

\section{Mentransfer Pengetahuan}

Isu berikutnya setelah pengetahuan yang telah diurai kekusutannya dan repositorinya yang representatif telah tersedia adalah bagaimana mentransfer pengetahuan tersebut kedalam repositori yang ada. Hal ini menjadi isu tersendiri karena: 1) struktur pengetahuan yang telah diurai kekusutannya dan struktur repositori itu sendiri bisa saja berbeda. Hal ini tidak mengherankan karena proses pengembangan kedua hal berbeda tersebut tentu saja berbeda dan didekati dengan metodologi yang berbeda pula.

Dalam domain SI, Syriani et al. (2013) misalnya, telah mengusulkan sebuah solusi untuk hal ini dengan memanfaatkan sebuah pendekatan dengan rasionalitas bahwa: jika ada 2 buah model akan dihubungkan, yangmana konten sebuah model akanditransferke model lainya maka aktivitas tersebut dapat didekati sebagai sebuah pendekatan transformasi model-to-model (MtM). Formulasi MtM ini sudah berkembang cukup matang dalam bidang rekayasa perangkat lunak (software engineering). Sebagaimana yang ditunjukan oleh Inan et al. (2017)for recurring disasters (e.g. floods dalam berbagai penelitian mereka. Dengan memanfaatkan transformasi MtM, proses transfer antara pengetahuan yang telah diurai secara holistikdimungkinkan untuk dilaksanakan.

Namun demikian, walaupun sebuah kerangka kerja (framework)sebagai sebuah kontribusi utama tentang bagaimana pengetahuan best practice aktifitas $\mathrm{PB}$ ditransformasikan telah ditunjukan proses tentang bagaimana sistem pendukung keputusan PB yang holistik belum ditunjukan secara jelas. Hal ini telah disadari juga sebagaimana yang telah disampaikan dalam penelitian sebelumnya. Sistem pendukung keputusan yang bergantung pada pengetahuan yang lengkap dan holistik ini akan berdampak pada keputusan yang lebih baik pada berbagai aktivitas PB. Oleh karena itu, maka hal initelah menjadi dasar yang memicu berbagai penelitianlanjutan dalam bidang PB khususnya dalam memanfaatkan pengetahuan dalam mendukung aktivitas PB yang tangguh (disaster management resilience endeavours)

\section{KESIMPULAN}

Dalam uraian yang telah disampaikan diatas dapat disimpulkan bahwa riset dalam bidang PBsaat ini telah memberikan perhatian yang lebih serius pada bagaimana pemanfaatan pengetahuan, khususnya pengetahuan best practice PB. Pemanfaatan pengetahuan tersebut dianggap lebih efisien dan bisa sangat efektif dalam proses PB karena tidak ada bencana yang identik. Karena itu tidak ada sebuah metodologi yang dapat digunakan secara hibrid untuk diterapkan dan bekerja efektif dalam setiap aktivitas PB.

Pengetahuan yang lengkap dan terintegrasi, walaupun dipandang dapat menjawab tantangan ini, namun haruslah dapat merepresentasikan berbagai urgensi pada tiap titik lini masa proses $\mathrm{PB}$, yaitu pada tingkatan: pengambilan keputusan - perencanaan dan pada level penanganannya di lapangan. Hal ini dapat menjadi indikasi bahwa pengetahuan tersebut dapat menjadi landasan aktivitas sesuai dengan PB secara alamiah. Dengan 
demikian maka membekali pengetahuan terbaik pada setiap entitas yang terlibat dalam proses PB adalah hal yang dipandang efektif dan efisien.

Namun demikian hal ini tidak berarti bahwa berbagai pendekatan lainnya kurang tepat dalam riset PB karena kurang efektif dan efisien, misalnya pendekatan simulasi dengan berbagai pemodelan komputer dan atau matematis. Faktanya, simulasi keadaan bencana sangat bermanfaat terutama dalam memberikan informasi tentang sistem deteksi awal (early warning system) sebuah potensi bencana.

Namun demikian, menyediakan pengetahuan yang lengkap dan holistikpada setiap tahapan proses PB bagi setiap entitas setelah sistem peringatan dini, dinilai dapat sangat efektif mengurangi dampak negatif akibat bencana tersebut. Perlu diingat dalam banyak kasus bencana, kerusakan dan bahkan kematian terjadi bukan disebabkan karena bencana itu sendiri namun karena berbagai hallain yang tidak berhubungan langsung dengan bencana, misalnya karena panik, tidak mengerti apa yang harus dilakukan, dll (Hiwasaki et al., 2014).

Pengetahuan tersebut menjadi panduan yang lengkap setiap tindakan dalam setiap PB. Sebab belajar dari pengalaman terbaik (best practice) aktivitas sebuah PB dan kemudian diadopsi dan diadaptasi untuk penanganan bencana sejenis ditempat lain dipandang dapat memberikan ruang yang lebih bagi para stakeholderdalam memberikan respon yang tepat dan proporsional sebuah PB. Hal ini terjadi karena: 1) pemanfaatan pengetahuan dapat langsung dipahami mereka yang mengadopsinya karena menggunakan bahasa yang dimengerti oleh manusia; 2) pengetahuan dapat dibentuk sesuai tingkatan yang berbeda dan sesuai dengan keperluan aktivitas PB itu sendiri, misalnya pengetahuan yang sesuai dengan mereka yang berada pada tingkatan pengambilan keputusan - perencanaan dan yang sesuai dengan mereka yang ada pada garis depan penanganan bencana.

Namun demikian, merepresentasikan berbagai pengetahuan best practice dari berbagai aktivitas PB adalah hal yang sangat sulit dilakukan. Pengetahuan tersebut bisa saja disimpan dalam berbagai format yang oleh karenanya membutuhkan berbagai metodologi yang representatif untuk memotretnya. Walaupundalam penelitian sebelumnya, sebuah pendekatan dengan memanfaatkan sistem ifnrmasi telah diadopsi untuk mewujudkan hal ini, namun sumber yang digunakan dibatasi pada pengetahuan yang masih berada dalam format semi-struktur. Untuk berbagai format yang lainnya, misalnya tidak terstrukturatau bahkan belum distruktur, diperlukan penelitian lanjutan untuk mewujudkannya.

Hal yang perlu juga dipahami adalah bahwa berbagai kontribusi yang dihasilkan pada penelitian lanjutan tersebut haruskah dapat dievaluasi dengan berbagai metode evaluasi yang sesuai dan ketat (robust dan rigor) untuk menjamin kemanjurannya dan kemanfaatannya secara akademis dan praktis (theoretical and practical contribution).

\section{A. Agenda Riset ke Depan}

Dengan melakukan telaah literatur tentang berbagai penelitian terbaru dalam riset $\mathrm{PB}$, khususnya tentang bagaimana pengetahuan best practice berbagai aktifitas PB dapat dimanfaatkan dalam mendukung pengembangan ketahanan bencana maka agenda riset kedepan dapat juga bentuk.

Pertama, sebagaimana yang telah dijelaskan bahwa walaupun berbagai kontribusi telah dilakukan dalam bidang riset ini, namun berbagai kesempatan sekaligus tantangan juga terbuka. Tepatnya, tantangan dan kesempatan dalam memperbaiki pendekatan-pendekatan yang ada dan juga dimungkinkan untuk pengembangan dan penemuan berbagai pendekatan baru yang lebih tepat sesuai dengan masalah yang dihadapi.

Kedua, kesempatan untuk mendorong riset penanganan bencana yang lebih formal dan sistematis dalam sebuah grup riset, misalnya pada level universitas. Hal ini disebabkan karena Indonesia sebagai sebuah negara,faktanya,adalah sebuah laboratorium yang relatif paling lengkap dalam hal kebencanaan. Hal ini karena, dengan berbagai karakteristik alamnya, Indonesia memilik hampir semua bentuk bencana, misalnya erupsi gunung berapi, kebakaran, angin topan, banjir, gempa bumi, tsunami, dan lain sebagainya. Dengan demikian maka berbagai potensi bencana tersebut dapat menjadi studi kasus terbaik yang sangat bermanfaat dalam melakukan riset kebencanaan. Sehingga 
kontribusi yang jelas bagi berbagai persoalan nyata yang ada akan dapat diwujudkan dalam bentuk konkrit. Hal ini juga sesuai dengan program pemerintah yang mendeskripsikan riset kebencanaan dalam prioritas ke-5 dari kesepuluh prioritas bidang riset nasional dalam era milenial saat ini.

Ketiga, hal ini secara otomatis juga akan memberikan gambaran yang cukup jelas bagi mereka yang tertarik dan sedang mencari topik riset untuk studi Doktoral mereka dalam riset kebencaaan, khususnya dalam riset pemanfaatan pengetahuan best practice $\mathrm{PB}$. Sehingga diharapkan, riset yang dihasilkan dapat memberikan kontribusi yang lebih mendalam dalam domain ini, tidak hanya praktis dan teoritis namun sampai pada pemahaman filosofis bidang tersebut.

Keempat, dengan memahami pentingnya proses belajar dari pengalaman (learning from the best experience), maka riset dalam bidang lain yang juga terbuka luas. Hal ini disebabkan karena bejalar dari pengalaman terbaik terjadi pada hampir semua tingkatan dan disiplin. Misalnya dalam bidang pemerintahan. Pergantian posisi jabatan tak bisa dihindari. Sebuah sistem yang baik dalam proses belajar akan mengijinkan mereka yang baru menempati sebuah jabatan tertentu pada pemerintahan dapat dengan cepat beradaptasi karena terdapat pengetahuan yang lengkap yang dapat diakses dengan mudah dalam menunjang kerja mereka pada posisi baru tersebut. Begitu juga pada berbagai bidang lainya.

Kelima, pemenfaatan TIK, dalam hal ini adalah pengembangan sebuah knowledge-based information system of disaster management, untuk membantu manajemen proses PB yang lebih baik perlu diupayakan. Hal ini mengingat tingkat kematangan teknologi informasi itu sendiri dalam pengembangan sebuah perangkat perangkat lunak sistem informasi yang sudah relatif cukup matang. Disamping itu, sifat hadirnya TIK yang dimaksudkan untuk mewujudkan efektifitas dan efisiensi proses yang terjadi. Efisiensi dan efktifitas pemanfaatan TIK itu juga sendiri, dalam konteks ini, dimaksudkan untuk menjawab berbagai tantangan jarak, geografisdan waktu. Terutama dalam konteks Indonesia (secara spesifik adalah Tanah Papua: Provinsi Papua dan Papua Barat) pemanfaatan sistem informasi dalam mengelula berbagai pengetahuan best practices sangat dianjurkan mengingat tantangan geografis, jarak dan waktu yang begitu tinggi.

\section{UCAPAN TERIMA KASIH}

Penulis mengucapkan banyak terima kasih kepada dekan dan kawan-kawan dosen di Fakultas Teknik Universitas Papua Manokwari, yang sudah banyak memberikan saran maupun kritik bagi penyempurnaan hasil riset ini

\section{Daftar Pustaka}

Benaben, F., Lauras, M., Truptil, S., \& Salatge, N. (2016). A Metamodel for Knowledge Management in Crisis Management. 2016 49th Hawaii International Conference on System Sciences (HICSS), 126-135. https:// doi.org/10.1109/HICSS.2016.24

Beydoun, G., Low, G., Henderson-Sellers, B., Mouratidis, H., Gomez-Sanz, J. J., Pavon, J., \& Gonzalez-Perez, C. (2009). FAML: A Generic Metamodel for MAS Development. IEEE Transactions on Software Engineering, 35(6), 841-863. https://doi.org/10.1109/ TSE.2009.34

Blackman, D., Nakanishi, H., \& Benson, A. M. (2017). Disaster resilience as a complex problem: Why linearity is not applicable for long-term recovery. Technological Forecasting and Social Change, 121(Agustus), 89-98. https://doi. org/10.1016/j.techfore.2016.09.018

bnpb.go.id. (2019a). Ini Tiga Faktor Penyebab Banjir Bandang Sentani. Bnpb.Go.Id. https://bnpb.go.id/ini-tiga-faktorpenyebab-banjir-bandang-sentani

bnpb.go.id. (2019b). Kepala BNPB Meninjau Jayapura Pasca Banjir Bandang. https:// bnpb.go.id/kepala-bnpb-meninjaujayapura-pasca-banjir-bandang

Briceño, S. (2015). Looking Back and Beyond Sendai: 25 Years of International Policy Experience on Disaster Risk Reduction. International Journal of Disaster Risk Science, 6(1), 1-7. https://doi. org/10.1007/s13753-015-0040-y

Cavallo, A., \& Ireland, V. (2015). Preparing for Complex Interdependent Risks: A System of Systems Approach to Building Disaster Resilience. https://www.preventionweb. net/english/hyogo/gar/2015/en / bgdocs/Cavallo and Ireland, 2014.pdf

Chatfield, A. T., Reddick, C. G., Inan, D. I., \& Brajawidagda, U. (2014). E-government, 
social media, and risk perception communication at the edge of disaster. Proceedingsofthe 15th Annual International Conference on Digital Government Research - Dg.o '14, 153-162. https://doi. org/10.1145/2612733.2612752

Chen, N., Du, W., Song, F., \& Chen, Z. (2015). FLCNDEMF: An Event Metamodel for Flood Process Information Management under the Sensor Web Environment. Remote Sensing, 7(6), 7231-7256. https:// doi.org/10.3390/rs70607231

Coppola, D. (2011). Introduction to International Disaster Management 2nd Edition. https:// www.elsevier.com/books/introductionto-international-disaster-management/ coppola/978-0-12-382174-4

Coppola, D. P. (2006). Introduction to International Disaster Management. Elsevier.

Delir Haghighi, P., Burstein, F., Zaslavsky, A., \& Arbon, P. (2013). Development and evaluation of ontology for intelligent decision support in medical emergency management for mass gatherings. Decision Support Systems, 54(2), 11921204. https://doi.org/10.1016/j. dss.2012.11.013

detikcom. (2019). Jumlah Pengungsi Banjir Bandang Sentani Capai 11.156 Orang. Detik.Com. https://news.detik.com/ berita/d-4478389/jumlah-pengungsibanjir-bandang-sentani-capai-11156orang

Dorasamy, M., Raman, M., \& Kaliannan, M. (2017). Integrated community emergency management and awareness system: A knowledge management system for disaster support. Technological Forecasting and Social Change, 121(August), 139-167. https://doi.org/10.1016/j. techfore.2017.03.017

Fogli, D., Greppi, C., \& Guida, G. (2017). Design patterns for emergency management: An exercise in reflective practice. Information \& Management, 54(7), 971-986. https:// doi.org/10.1016/j.im.2017.02.002

Grolinger, K., Mezghani, E., Capretz, M. A. M., \& Exposito, E. (2015). Collaborative knowledge as a service applied to the disaster management domain. International Journal of Cloud Computing, $4(1), \quad 5 . \quad$ https://doi.org/10.1504/
IJCC.2015.067706

Hiwasaki, L., Luna, E., Syamsidik, \& Marçal, J. A. (2015). Local and indigenous knowledge on climate-related hazards of coastal and small island communities in Southeast Asia. Climatic Change, 128(1-2), 35-56. https://doi.org/10.1007/s10584-0141288-8

Hiwasaki, L., Luna, E., Syamsidik, \& Shaw, R. (2014). Process for integrating local and indigenous knowledge with science for hydro-meteorological disaster risk reduction and climate change adaptation in coastal and small island communities. International Journal of Disaster Risk Reduction, 10(Part A), 15-27. https://doi. org/10.1016/j.ijdrr.2014.07.007

Horita, F. E. A., de Albuquerque, J. P., Marchezini, V., \& Mendiondo, E. M. (2017). Bridging the gap between decision-making and emerging big data sources: An application of a model-based framework to disaster management in Brazil. Decision Support Systems, 97(May), 12-22. https://doi. org/10.1016/j.dss.2017.03.001

Inan, Dedi I., \& Beydoun, G. (2017). Facilitating Disaster Knowledge Management with Agent-Based Modelling. Pacific Asia Conference on Information System, 1-17. https://www.researchgate.net/ publication/326803625_Facilitating_ Disaster_Knowledge_Management_with_ Agent-Based_Modelling

Inan, Dedi Iskandar, Beydoun, G., \& Opper, S. (2017, February 25). Customising Agent Based Analysis Towards Analysis of Disaster Management Knowledge. Australasian Conference on Information Systems 2016. http://arxiv.org/abs/1702.07979

Inan, Dedi Iskandar, Beydoun, G., \& Opper, S. (2018). Agent-Based Knowledge Analysis Framework in Disaster Management. Information Systems Frontiers, 20(4), 783802. https://doi.org/10.1007/s10796017-9792-9

Inan, Dedi Iskandar, Beydoun, G., \& Opper, S. (2015). Towards Knowledge Sharing in Disaster Management: an Agent Oriented Knowledge Analysis Framework. 26th Australasian Conference on Information Systems, 1-13. https://ro.uow.edu.au/cgi/ viewcontent.cgi 
Lauras, M., Truptil, S., \& Bénaben, F. (2015). Towards a better management of complex emergencies through crisis management meta-modelling. Disasters, 39(4), 687714. https://doi.org/10.1111/disa.12122

Mejri, O., \& Pesaro, G. (2015). Knowledge based strategies for Disaster Risk Reduction: A knowledge management framework to increase understanding and awareness of value of prevention and preparedness. Safety and Reliability of Complex Engineered Systems, 3589-3596. https:// doi.org/10.1201/b19094-472

Mescherin, S. A., Kirillov, I., \& Klimenko, S. (2013). Ontology of Emergency Shared Situation Awareness and Crisis Interoperability. 2013 International Conference on Cyberworlds, 159-162. https://doi.org/10.1109/CW.2013.61

Othman, S. H., \& Beydoun, G. (2016). A metamodel-based knowledge sharing system for disaster management. Expert Systems with Applications, 63, 49-65. https://doi.org/10.1016/j. eswa.2016.06.018

Othman, S. H., Beydoun, G., \& Sugumaran, V. (2014). Development and validation of a Disaster Management Metamodel (DMM). Information Processing \& Management, 50(2), 235-271. https://doi. org/10.1016/j.ipm.2013.11.001

Paré, G., Trudel, M.-C., Jaana, M., \& Kitsiou, S. (2015). Synthesizing information systems knowledge: A typology of literature reviews. Information \& Management, 52(2), 183-199. https://doi.org/10.1016/j. im.2014.08.008

Poslad, S., Middleton, S. E., Chaves, F., Tao, R., Necmioglu, O., \& Bugel, U. (2015). A Semantic IoT Early Warning System for Natural Environment Crisis Management. IEEE Transactions on Emerging Topics in Computing, 3(2), 246-257. https://doi. org/10.1109/TETC.2015.2432742
Rivera, C., Tehler, H., \& Wamsler, C. (2015). Fragmentation in disasterriskmanagement systems: A barrier for integrated planning. International Journal of Disaster Risk Reduction, 14(4), 445-456. https://doi. org/10.1016/j.ijdrr.2015.09.009

Syriani, E., Gray, J., \& Vangheluwe, H. (2013). Modeling a Model Transformation Language. In Domain Engineering (pp. 211-237). Springer Berlin Heidelberg. https://doi.org/10.1007/978-3-64236654-3_9

Thapa, D., Budhathoki, N., \& Munkvold, B. E. (2017). Analyzing Crisis Response through Actor-Network Theory: The Case of Kathmandu Living Labs. Communications of the Association for Information Systems, 41, 414-428. https://doi. org/10.17705/1CAIS.04119

UNISDR. (2014). Risk Sensitive Development as the Cornerstoneof Resilience and Sustainability. https://www. preventionweb.net/documents/posthfa/ HFA_input_document_Asia_Pacific.pdf

UNISDR. (2015). Disaster Risk Reduction and Resilience in the 2030 Agenda for Sustainable Development. https:// www.un is d r.org/files / 46052 . disasterriskreductioninthe2030agend.pdf

Wang, X.-L., \& Wu, X.-L. (2012). A Novel Knowledge Representation Method Based on Ontology for Natural Disaster DecisionMaking.2012 IEEE International Conference on Computer Science and Automation Engineering (CSAE), 241-245. https://doi. org/10.1109/CSAE.2012.6272947

Webster, J., \& Watson, R. T. (2002). Analyzing the Past to Prepare for the Future : Writring a Literatue Review. MIS Quarterly, 26(2), xiiixxiii. https://doi.org/10.2307/4132319

Weichselgartner, J., \& Pigeon, P. (2015). The Role of Knowledge in Disaster Risk Reduction. International Journal of Disaster Risk Science, 6(2), 107-116. https://doi. org/10.1007/s13753-015-0052-7 